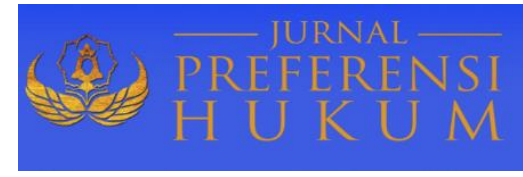

Jurnal Preferensi Hukum | ISSN: XXXX | E-ISSN: XXXX

Vol. 1 No. 1 - Juli 2020 hal. 207-213| Available online at https://www.ejournal.warmadewa.ac.id/index.php/juprehum

\title{
PERTIMBANGAN HAKIM DALAM MENJATUHKAN PIDANA TERHADAP TINDAK PIDANA PENCURIAN DENGAN PEMBERATAN YANG DILAKUKAN OLEH ANAK
}

\author{
Ida Bagus Agung Pariama Manuaba, I Nyoman Sujana, Ni Made Sukaryati Karma \\ Universitas Warmadewa, Bali, Denpasar, Indonesia
}

\begin{abstract}
Abstrak
Pertimbangan Hakim adalah hal-hal yang menjadi dasaratau yang dipertimbangkan hakim dalam memutus suatu perkara tindak pidana. Tindak Pidana Pencurian adalah sebuah perbuatan yang digolongkan sebagai tindak pidana umum di mana terjadinya kejahatan terhadap harta benda milik orang lain. Pencurian dengan Pemberatan adalah tindak pidana pencurian yang dalam pelaksanaannya disertai oleh unsurtertentu sehingga bersifat lebih berat dan diancam dengan hukuman yang lebih tinggi. Anak ialah seorang yang belum berusia delapan belas (18) tahun termasuk yang masih dalam kandungan. Dalam penyelesaian perkara anak, hakim wajib mempertimbangkan laporan dalam persidangan mengenai anak yang bersangkutan. Penelitian ini bertujuan untuk mengetahui pertimbangan dan sanksi pidana yang dijatuhkan oleh hakim pada pidana pencurian dengan pemberatan yang dilakukan oleh anak. Penelitian ini menggunakan metode penelitian hukum normative dengan pendekatan perundang-undangan, pendekatan konseptual dan pendekatan kasus. Bahan hukum yang dikaji adalah bahan hukum primer, bahan hukum sekunder dan bahan hukum tersier. Hasil dari penelitian ini menunjukkan pertimbangan hakim dalam menjatuhkan pidana terhadap anak yang melakukan tindak pidana pencurian dengan pemberatan berdasarkan pada unsur-unsur tindak pidana yang dilakukan serta hal-hal yang meringankan dan memberatkan pidana terhadap anak. Sanksi pidana yang dijatuhkan oleh hakim terhadap anak yang melakukan tindak pidana pencurian dengan pemberatan berdasarkan Putusan Pengadilan serta ketentuan Pasal 363 ayat (1) ke-4 KUHP jungto Pasal 65 ayat (1) KUHP dan hukum lainnya yang berkaitan dengan perkara tersebut menyatakan anak terbukti secara sah dan meyakinkan bersalah serta menjatuhkan Pidana terhadap anak dengan pidana penjara selama tujuh bulan.
\end{abstract}

Kata Kunci: Hakim; Tindak Pidana; Pencurian; Pemberatan; Anak

\begin{abstract}
Judge's considerations are matters which are the basis or are considered by the judge in deciding a crime case. Crime Theft is an act that is classified as a general crime in which a crime against the p roperty of another person. Theft with weighting is a criminal act of theft which in its implementation is accompanied by certain elements so that it is more severe and threatened with higher penalties. Child is a person who is not yet eighteen (18) years old, including those who are still in the womb. In settling a child case, the judge must consider the report in the trial regarding the child concerned. This study aims to determine the criminal considerations and sanctions imposed by the judge on criminal theft with weighting carried out by children. This study uses a normative legal research method with a statutory approach, conceptual approach and case approach. The legal materials studied are primary legal materials, secondary legal materials and tertiary legal materials. The results of this study indicate the judge's judgment in imposing a crime against a child who commits a crime of theft by weighting it based on the elements of the crime committed as well as things that alleviate and incriminate the crime against the child. Criminal sanctions imposed by a judge against a child who commits an act of theft by weighting based on the Court's Decision and the provisions of Article 363 paragraph (1) of the 4th KUHP jungto Article 65 paragraph (1) of the Criminal Code and other laws relating to the case state that the child is proven legally and convincingly guilty as well as convicting a child of seven months in prison.
\end{abstract}

Keywords: Judge, Crime, Theft, Objection, Children

\section{PENDAHULUAN}

Kekuasaan kehakiman adalah badan yang menetapkan kekuatan kaidah hukum positif dalam konkretisasi atau individualisasi peraturan hukum yang bersifat umum oleh hakim melalui putusannya. Semua peraturan perundang- undangan yang dibuat oleh negara dalam upaya menjamin keselamatan dan kesejahteraan masyarakat tidak akan ada artinya bila tidak ada kekuasaan kehakiman yang 
diwujudkan dalam bentuk peradilan yang bebas dan tidak memihak sebagai suatu unsur Negara Hukum (Rifai 2010).

Hakim yang memiliki kedudukan yang bebas diwajibkan untuk tidak memihak. Hakim yang tidak memihak artinya hakim wajib untuk menjamin segala kebutuhan sesuai dengan hak asasi manusia khususnya bagi tersangka atau terdakwa. Hal ini sudah jadi kewajiban hakim untuk mewujudkan persamaan kedudukan di depan hukum bagi setiap warga negara (Hamzah and Waluyo 1998).

Dasar pertimbangan hakim dalam memutus perkara pidana berdasarkan teori atau hasil penelitian yang berkaitan, ditemukan hasil penelitian yang maksimal dan seimbang dalam teori dan praktek. Mengingat bahwa kejahatan semakin meresahkan segenap lapisan masyarakat maka peran hakim sebagai aparat penegak hukum sangat diperlukan. Salah satu jenis kejahatan yang meresahkan segenap lapisan masyarakat adalah tindak pidana pencurian bahkan dengan unsur memberatkan atau pencurian kualifikasi yang diatur dalam Pasal 363 KUHP. Tidak tanggung- tanggung pelaku tindak pidana pencurian-pun dilakukan oleh seorang anak. Pencurian yang dilakukan oleh anak di bawah umur diartikan sebagai suatu pencurian dengan cara-cara tertentu sehingga bersifat lebih ringan, namun dalam ketentuan hukum pidana dapat saja diancam dengan hukuman yang maksimumnya lebih tinggi (Tambalean 2013).

Dalam menyelesaikan perkara anak, hakim wajib untuk mempertimbangkan laporan hasil penelitian masyarakat yang dihimpun oleh pembimbing kemasyarakatan. Dengan terdapatnya hasil laporan itu hakim diharapkan dapat memberikan putusan yang adil bagi anak yang bersangkutan.

Setiap putusan hakim akan memengaruhi masa depan anak yang bersangkutan karena itu hakim harus yakin bahwa putusan yang diambil bisa menjadi dasar yang kuat untuk mengantar anak menuju masa depan yang lebih baik serta membangun dirinya untuk jadi warga yang bertanggung jawab bagi keluarga bangsa dan negara (Setiawan 2015).

Pemberian sanksi pidana terhadap anak tidak semua sama walaupun melanggar ketentuan yang sama dalam KUHP. Sebab hakim dalam memberikan sanksi pidana terhadapanak wajib memiliki dasar pertimbangan yang sesuai dengan kebutuhan anak, keadilan bagi korban, ketertiban masyarakat, serta teori tujuan pemidanaan dalam hukum pidana. Dengan demikian diharapkan putusan hakim yang dijatuhkan terhadap anak yang melakukan tindak pidana adalah keputusan yang bijak dan adil bagi semua pihak (Wafi 2019).

Dalam perkara pidana pada Pengadilan Negeri Denpasar Reg. Nomor 02/Pid.SusAnak/2019/PN.DPS seorang anak bersama rekannya telah melakukan tindak pidana pencurian dengan pemberatan dan hakim telah memutus perkara tersebut dengan menjatuhkan pidana penjara terhadap anak tersebut.

Pada penelitian serupa diungkapkan bahwa dasar pertimbangan Hakim dalam menjatuhkan sanksi pidana penjara terhadap anak sebagai pelaku tindak pidana pencurian dengan pemberatan yaitu berdasarkan pertimbangan Yuridis dan Non Yuridis (Andre 2018; Noviana 2018; Pratama, Rozah, and Sri 2016). Pertimbangan yuridis yaitu pertimbangan hakim yang didasarkan fakta-fakta yang terungkap dalam persidangan dan Undang-Undang yang telah ditetapkan (Zhasadoma 2015) dan non yuridis yaitu keadaan yang berkaitan dengan anak meliputi latar belakang, akibat, kondisi, keadaan sosial serta ekonomi anak korban (Mutiaramadani 2014; Nugroho 2012).

Berdasarkan uraian latarbelakang di atas terdapat dua rumusan masalah pada penelitian ini, yaitu bagaimana pertimbangan hakim dalam menjatuhkan pidana pencurian dengan pemberatan yang dilakukan oleh anak? Dan bagaimana sanksi pidana yang dijatuhkan oleh hakim terhadap tindak pidana pencurian dengan pemberatan yang dilakukan oleh anak? Dari rumusan masalah tersebut, penelitian ini bertujuan untuk mengetahui pertimbangan hakim dalam menjatuhkan pidana terhadap anak sebagai pelaku tindak pidana pencurian dengan pemberatan dan sanksi pidana yang dijatuhkan oleh hakim terhadap anak sebagai pelaku tindak pidana pencurian dengan pemberatan.

\section{METODE PENELITIAN}

Metode penelitian yang dipakai dalam penelitian ini ialah metode penelitian hukum normative. Metode penelitian hukum normative disebut juga penelitian hukum kepustakaan ialah metode yang dilakukan dengan cara meneliti bahan pustaka yang ada. Sedangkan pendekatan masalah yang digunakan secara yuridis kasus yaitu dengan meninjau peraturan perundang-undangan yang berhubungan dengan kasus. Adapun sumber bahan hukum yang digunakan yaitu sumber bahan hukum primer, sekunder, dan tersier. Sumber bahan hukum primer, yaitu bahan-bahan yang bersifat mengikat berupa peraturan perundang- 
undangan yang meliputi UUD NRI Tahun 1945, KUHP, KUHAP, UU No. 48 Tahun 2009 tentang Kekuasaan Kehakiman, UU No 11 Tahun 2012 tentang Sistem Peradilan Pidana Anak. Sumber bahan hukum Sekunder yaitu bahan-bahan hukum yang didapat dengan cara studi pada buku literature dan hasil penelitian yang berhubungan dengan pokok masalah. Dan sumber bahan hukum Tersier yaitu bahan-bahan hukum yang mendukung bahan hukum primer dan bahan hukum sekunder seperti Kamus Hukum KBBI dan Internet.

\section{HASIL DAN PEMBAHASAN}

\section{Pertimbangan Hakim Dalam Menjatuhkan Pidana Pencurian Dengan Pemberatan Yang Dilakukan Oleh Anak}

Tindak pidana pencurian adalah perbuatan yang digolongkan sebagai tindak pidana umum di mana terjadinya kejahatan terhadap harta benda. Kejahatan terhadap harta benda merupakan penyerangan terhadap kepentingan hukum atas harta benda milik orang lain.

Tindak pidana pencurian dengan pemberatan termasuk dalam pasal 363 KUHP. Tindak pidana pencurian dengan pemberatan disebut juga pencurian dengan kualifikasi. Yang dimaksud dengan pencurian dengan pemberatan ialah pencurian biasa yang disertai keadaan tertentu yang bersifat memberatkan sehingga diancam dengan hukuman penjara minimal 7 (tujuh) tahun dan maksimal 9 (sembilan) tahun (Soesilo 1984).

Dasar-dasar tindak pidana pencurian dengan pemberatan terdapat dalam KUHP dalam Pasal 362 KUHP sebagai dasar pokok dari tindak pidana pencurian biasa dengan Pasal 363 KUHP yang menjelaskan tentang tindak pidana pencurian yang disertai dengan pemberatan. Dasar-dasar tindak pidana pencurian dengan pemberatan dalam Pasal 363 KUHP yaitu

1. Pencurian Ternak

2. Pencurian yang dilakukan pada waktu adanya bencana

3. Percurian yang dilakukan pada malam hari di dalam rumah atau pekarangan tertutup

a. Adanya unsur malam hari

b. Adanya unsur dalam sebuah rumah

c. Adanya unsur pekarangan tertutup

4. Pencurian yang dilakukan oleh dua orang atau lebih

5. Pencurian yang dilakukan dengan merusak atau memanjat dengan memakai kunci palsu atau perintah palsu
a. Adanya unsur merusak
b. Adanya unsur memanjat
c. Adanya unsur memakai kunci palsu
d. Adanya unsur perintah palsu

Seorang anak melakukan tindak pidana pencurian seringkali didasarkan pada kondisi psikologi serta bujukan bahkan paksaan dari orang dewasa. Seorang anak yang melakukan tindak pidana akan mendapat sanksi pidana bagi anak yang terdapat pada Undang-Undang Nomor 11 Tahun 2012 tentang Sistem Peradilan Pidana Anak.

Dalam perkara pidana pada Pengadilan Negeri Denpasar Reg. Nomor 02/Pid.SusAnak/2019/PN.DPS terdapat kronologi sehingga anak dihadapkan dalam persidangan dengan dakwaan sebagai berikut

Bahwa anak Kadek Bram Sastra Wijaya Pucangan bersama dengan saksi I Gede Agus Praptananda (terdakwa dalam berkas penuntutan terpisah) pada hari Senin tanggal 26 Maret 2018 sekitar pukul 24.00 wita dan pada hari Jumat tanggal 30 Maret 2018 sekitar pukul 24.00 wita bertempat didepan Toko Rata Kanan Game Online Jalan Siulan Nomor 224 Denpasar Timur dan di Jalan Sedap Malam Gang Seruni Nomor 4A Denpasar Timur atau setidaknya pada tempat tertentu yang masih termasuk dalam daerah hukum Pengadilan Negeri Denpasar yang berwenang memeriksa dan mengadili perkara ini telah mengambil barang milik orang lain dengan maksud ingin memiliki secara melawan hukum yang dilakukan oleh dua orang atau lebih.

Hakim dalam memutus perkara terhadap anak sebagai pelaku tindak pidana mempertimbangkan hal-hal yang meringankan dan memberatkan. Hal ini sudah ditentukan dalam Pasal 197 Ayat (1) huruf (f) KUHAP yang menyebutkan putusan pemidanaan memuat tentang keadaan yang meringankan dan yang memberatkan terdakwa. 
Hal-hal yang meringankan dan memberatkan dalam memutus suatu perkara pidana terdapat dalam KUHP yaitu sebagai berikut:

1. Hal yang meringankan

Dalam KUHP mengatur hal-hal yang menjadi alasan yang meringankan pidana, yaitu:

a. Percobaan

b. Sebagai pembantu

c. Belum dewasa

2. Hal-hal yang memberatkan

KUHP juga mengatur hal-hal yang dijadikan alasan yang memberatkan pidana, yaitu:

a. Jabatan

b. Pengulangan

c. Penggabungan

Berdasarkan Surat Penetapan Majelis Hakim Pengadilan Negeri Denpasar Reg. Nomor 02/Pid.Sus.Anak/2019/PN.Dps. majelis hakim mempertimbangkan hal-hal yang meringankan dan memberatkan pidana terhadap anak pelaku tindak pidana pencurian dengan pemberatan.

Adapun hal-hal yang meringankan dalam putusan tersebut, yaitu:

a. Anak mengaku bersalah dan menyesal

b. Anak mengakui terus terang perbuatannya

c. Korban sudah memaafkan perbuatan anak dan sudah ada pencabutan laporan dalam berkas perkara.

Dan hal-hal yang memberatkan dalam putusan tersebut, yaitu:

a. Perbuatan anak telah merugikan korban I Kadek Nanda Dwi Kusuma dan saksi korban I Gede Doni Supardi.

\section{Sanksi Pidana yang Dijatuhkan oleh Hakim terhadap Tindak Pidana Pencurian dengan Pemberatan yang Dilakukan oleh Anak}

Anak ialah harapan bangsa dan akan menjadi generasi penerus bagi kehidupan bangsa dan negara sehingga anak perlu dibimbing dengan baik agar anak tidak terjerumus dalam kehidupannya kelak. Orangtua, keluarga, masyarakat dan pemerintah wajib untuk memberi perhatian terhadap pertumbuhan dan perkembangan anak (Gultom 2012). Pada kasus tertentu, anak yang merupakan pelaku kejahatan diputuskan untuk kembali ke orang tua dianggap dapat memberikan efek jera (Artana, Budiartha, and Laba 2019).

John Lock mengungkapkan bahwa anak ialah pribadi peka terhadap lingkungannya. Anak tidak sama dengan orang dewasa di mana anak cenderung untuk menyimpang dari hukum yang disebabkan oleh keterbatasan pengetahuan terhadap realita kehidupan. Anak lebih mudah belajar dengan contohcontoh yang diterimanya dari aturan yang bersifat memaksa (Soemitro 1990).

Syarat pengenaan sanksi pidana terhadap anak sabagai pelaku tindak pidana pencurian dengan pemberatan berdasakan fakta-fakta yang ditemukan dalam persidangan sebagaimana dijelaskan dalam KUHAP.

Dalam KUHAP syarat-syarat pengenaan sanksi pidana terhadap anak sebagai pelaku tindak pidana pencurian dengan pemberatan, yaitu:

1. Adanya Barang Bukti

Dalam Pasal39 ayat (1) KUHAP menyebutkan tentang benda apa saja yang dapat disita sehingga benda-benda disebutkan dalam pasal disebut sebagai barang bukti. Dalam Surat Penetapan Majelis Hakim Pengadilan Negeri Denpasar Reg. Nomor 02/Pid.Sus.Anak/2019/PN.Dps. (Acara Pemeriksaan Biasa) terdapat beberapa barang bukti yaitu:

1) 1 (satu) unit motor honda scoopy warna krem tahun 2015 yang di STNK an. Ni Luh Putu Cintya Junita Sari

2) 1 (satu) unit motor honda scoopy warna krem cokelat tahun 2016 yang di STNK An. I Gede Doni Supardi

3) 1 (satu) unit motor honda scoopy warna hitam-merah

Barangbukti tersebut telah disita secara sahmenurut hukum karena itu dapat dipergunakan untuk memperkuat pembuktian dan barang bukti tersebut dibenarkan oleh para saksi dan anak sehingga berdasarkan Pasal 181 jungto 184 ayat (1) huruf d jungto Pasal 188 ayat (1) dan (2) KUHAP merupakan alat bukti yang sah pula berupa petunjuk. 


\section{Keterangan Saksi}

Keterangan saksi adalah alat bukti pertama dalam KUHAP yang pada umumnya tidak ada perkara yang luput dari pembuktian alat bukti keterangan saksi. Dalam Surat Penetapan Majelis Hakim Pengadilan Negeri Denpasar Reg. Nomor 02/Pid.Sus.Anak/2019/PN.Dps. berdasarkan keterangan para saksi dipersidangan yang dihubungkan dengan keterangan anak yang mana keterangannya saling bersesuaian satu dengan yang lainnya serta adanya barang bukti maka diperoleh suatu petunjuk bahwa anak telah terbukti melakukan tindak pidana pencurian dengan pemberatan.

\section{Analisis Yuridis}

Analisis yuridis merupakan analisis secara hukum yang berlaku baik hukum tertulis maupun lisan. Yuridis yang tertulis adalah peraturan perundang-undangan sedangkan yuridis yang berupa lisan adalah hukum adat.

Berdasarkan analisis yuridis dalam Surat Penetapan Majelis Hakim Pengadilan Negeri Denpasar Reg. Nomor 02/Pid.Sus.Anak/2019/PN Dps. terdapat fakta-fakta yang terungkap dalam persidangan maka sampailah kepada pembuktian mengenai unsur-unsur tindak pidana yang didakwakan yaitu melanggar Pasal 363 ayat (1) ke-4 KUHP jungto Pasal 65 ayat (1) KUHP dengan unsur-unsur sebagai berikut:

1) Unsur barang siapa

2) Unsur mengambil barang yang seluruhnya milik orang lain

Berdasarkan fakta-fakta dipersidangan berdasarkan keterangan saksi bahwa benar anak Kadek Bram Sastra Wijaya Pucangan mengambil 1 (satu) unit motor honda scoopy warna krem tahun 2015 yang di STNK an. Ni Luh Putu Cintya Junita Sari dan 1 (satu) unit motor honda scoopy warna krem cokelat tahun 2016 yang di STNK An. I Gede Doni Supardi. Dengan demikian unsur mengambil barang yang seluruhnya milik orang lain telah terpenuhi dan terbukti secara sah menurut hukum.

3) Unsur dengan maksud ingin memiliki secara melawan hukum

Berdasarkan fakta-fakta dipersidangan bahwa anak Kadek Bram Sastra Wijaya Pucangan mengambil 1 (satu) unit motor honda scoopy warna krem tahun 2015 dan 1 (satu) unit motor honda scoopy warna krem cokelat tahun 2016 tanpa izin dari pemilik motor tersebut dan kemudian menjualnya. Dengan demikian unsur dengan maksud ingin memiliki secara melawan hukum telah terpenuhi dan terbukti secara sah menurut hukum.

4) Unsur yang dilakukan oleh dua orang atau lebih

Berdasarkan fakta-fakta dalam persidangan bahwa benar anak Kadek Bram Sastra Wijaya Pucangan bersama dengan I Gede Agus Praptananda mengambil 1 (satu) unit motor honda scoopy warna krem tahun 2015 dan 1 (satu) unit motor honda scoopy warna krem cokelat tahun 2016 tersebut. Dengan demikian unsur yang dilakukan oleh dua orang atau lebih telah terpenuhi dan terbukti secara sah menurut hukum.

5) Unsur dalam hal perbarengan beberapa perbuatan yang harus dipandang sebagai perbuatan yang berdiri sendiri.

Berdasarkan fakta-fakta dalam persidangan berdasarkan keterangan saksi bahwa:

a) Benar pada hari senin tanggal 26 Maret 2018 anak Kadek Bram Sastra Wijaya Pucangan bersama I Gede Agus Praptananda mengambil 1 (satu) unit motor honda scoopy warna krem tahun 2015

b) Bahwa benar 3 hari kemudian pada hari Jumat tanggal 30 Maret 2018 anak Kadek Bram

Sastra Wijaya Pucangan bersama I Gede Agus Praptananda 1 (satu) unit motor honda scoopy warna krem cokelat tahun 2016.

Demikian unsur dalam hal perbarengan beberapa perbuatan yang harus dipandang sebagai perbuatan yang berdiri sendiri telah terpenuhi dan terbukti secara sah menurut hukum.

Dengan terpenuhinya semua unsur dalam Pasal 363 Ayat (1) ke-4 KUHP dari uraian-uraian pembuktian sebagaimana dimaksud di atas sebagai dasar dari apa yang telah didakwakan dalam dakwaan tunggal terbukti secara sah dan meyakinkan bersalah bahwa terdakwa anak telah melalukan tindak pidana pencurian dengan pemberatan.

Pengenaan sanksi pidana yang dilakukan oleh hakim terhadap anak yang melakukan tindak pidana pencurian dengan pemberatan menggunakan KUHP sebagai acuan dalam memberikan putusan di mana seorang anak yang melakukan tindak pidana seharusnya diberi sanksi berdasarkan Undang- 
Undang Nomor 11 Tahun 2012 tentang Sistem Peradilan Pidana Anak. Hal tersebut tidak sesuai dengan asas lex specialis derogat legi generalis yang artinya aturan hukum yang khusus akan mengesampingkan aturan hukum yang umum.

Dalam Putusan Pengadilan Negeri Denpasar Reg. Nomor 02/Pid.Sus.Anak/2019/PN.Dps. bahwa Putusan Pengadilan tersebut telah mendapat kekuatan hukum yang tetap pada tanggal 24 Januari 2019. Dalam Putusan Pengadilan tersebut memerhatikan Pasal 363 ayat (1) ke-4 KUHP Jungto Pasal 65 ayat (1) KUHP dan ketentuan hukum lain yang berkaitan dengan perkara tersebut sebagai berikut:

a. Menyatakan anak Kadek Bram Sastra Wijaya Pucangan terbukti secara sah dan meyakinkan menurut hukum melakukan tindak pidana pencurian dalam Keadaan Memberatkan

b. Menjatuhkan Pidana terhadap anak Kadek Bram Sastra Wijaya Pucangan oleh karena itu dengan pidana penjara selama 7 (tujuh) bulan

c. Menyatakan lamanya anak ditahan dikurangkan seluruhnya dari pidana yang telah dijatuhkan

d. Menetapkan anak untuk ditahan

e. Menetapkan barang bukti berupa:

1.1 (satu) unit motor honda scoopy warna krem tahun 2015 dengan nomor polisi DK 8446 IH beserta surat laporan kehilangan STNK

2. 1 (satu) unit motor honda scoopy warna krem cokelat tahun 2016 tanpa nomor polisi beserta STNK

3. 1 (satu) unit motor honda scoopy warna hitam merah dengan nomor polisi DK 4118 DP

beserta STNK Dipergunakan dalam berkas perkara atas nama I Gede Agus Praptananda

f. Membebankan kepada anak untuk membayar biaya perkara sebesar Rp.2.000- (dua ribu rupiah)

Dalam Berita Acara Pelaksanaan PutusanPengadilan perkara atas nama anak Kadek BramSastra Wijaya Pucangan dengan cara memasukan ke Lembaga Pemasyarakatan Denpasar untuk menjalani pidana penjara selama 7 (tujuh) bulan dikurangi selama anak berada dalam tahanan. Berdasakan Surat Perintah Kepala Kejaksaan Negeri Denpasar tanggal 04 Februari 2019 No. Print-567 / P.1.10 / Ep / 02 / 2019 telah melaksanakan Putusan Pengadilan Negeri Denpasar tanggal 24 Januari 2019 No. 2/Pid.Sus.Anak/2019/PN.Dps.

\section{SIMPULAN DAN SARAN}

\section{Simpulan}

Hakim dalam memutus perkara terhadap anak yang melakukan tindak pidana mempertimbangkan halhal yang meringankan dan memberatkan. Berdasarkan Surat Penetapan Majelis Hakim Pengadilan Negeri Denpasar Reg. Nomor 02/Pid.Sus.Anak/2019/PN.Dps. majelis hakim mempertimbangkan halhal yang meringankan seperti anak mengaku bersalah dan menyesal anak mengakui terus terang perbuatannya dan korban sudah memaafkan perbuatan anak dan sudah ada pencabutan laporan dalam berkas perkara. Sedangkan hal-hal yang memberatkan seperti perbuatan anak telah merugikan korban I Kadek Nanda Dwi Kusuma dan saksi korban I Gede Doni Supardi.

Hakim dalam menjatuhkan sanksi pidana terhadap anak sebagai pelaku tindak pidana pencurian dengan pemberatan berdasarkan Putusan Pengadilan Negeri Denpasar Reg. Nomor 02/Pid.Sus.Anak/2019/PN.Dps. bahwa dalam Putusan Pengadilan tersebut berdasakan Pasal 363 ayat (1) ke-4 KUHP Jungto Pasal 65 ayat (1) KUHP serta ketentuan hukum lainnya yang berkaitan dengan perkara tersebut menyatakan anak Kadek Bram Sastra Wijaya Pucangan terbukti secara sah dan meyakinkan bersalah melakukan tindak pidana pencurian dalam keadaan memberatkan dan menjatuhkan pidana terhadap anak Kadek Bram Sastra Wijaya Pucangan dengan pidana penjara selama 7 (tujuh) bulan.

\section{Saran}

Hakim dalam memutus perkara terhadap anak yang melakukan tindak pidana yang dijatuhkan dengan pidana penjara hendaknya perlu mempertimbangkan hal tersebut karena pidana penjara bukan solusi yang tepat untuk menyelesaikan perkara anak yang bermasalah dengan hukum. Pidana penjara dapat memberikan pengaruh yang buruk bagi anak baik secara psikologis dan status sosial yang berpengaruh bagi masa depan anak. Memberikan peringatan keras hingga sanksi pembinaan sosial pelatihan kerja dan sebagainya lebih baik diberlakukan bagi anak karena sanksi tersebut lebih memberikan pembinaan 
selain itu juga dapat merubah perilaku anak dalam kehidupan sosial serta melindungi hak dan masa depan yang dimiliki anak.

Orangtua anak hendaknya harus menjaga ruang lingkup pergaulan anak dan mengetahui aktifitas yang dilakukan oleh anak selain itu orangtua harus lebih banyak berkomunikasi dengan anak agar anak lebih memahami dan tidak terjerumus dalam tindak pidana. Mengingat semakin maraknya tindak pidana yang dilakukan oleh anak-anak sehingga mengakibatkan anak bermasalah dengan hukum.

\section{DAFTAR PUSTAKA}

Andre, Rahman. 2018. "Pertimbangan Hakim Dalam Menjatuhkan Pidana Penjara Terhadap Anak Pelaku Tindak Pidana Pencurian Dengan Pemberatan (Studi Di Pengadilan Negeri Kelas 1A Padang)." Universitas Andalas.

Artana, I. Wayan Jimmy, I. Nyoman Putu Budiartha, and I. Nengah Laba. 2019. "Dasar Pertimbangan Hakim Dalam Putusan Bebas Terhadap Pelaku Tindak Pidana Pencurian Yang Dilakukan Oleh Anak (Putusan Nomor: 9/PID.SUS ANAK/2017/PN.AMP).”Jurnal Analogi Hukum 1(2).

Gultom, Maidin. 2012. Perlindungan Hukum Terhadap Anak Dan Perempuan. Bandung: PT Refika Aditama.

Hamzah, Andi and Bambang Waluyo. 1998. Delik-Delik Terhadap Penyelenggaraan Peradilan (Conterm of Court). Jakarta: Sinar Grafika.

Mutiaramadani, Rara Kristi Aditya. 2014. "Dasar Pertimbangan Hakim Dalam Menjatuhkan Sanksi Pidana Penjara Terhadap Anak Sebagai Pelaku Tindak Pidana Pencurian Dengan Teori Pemidanaan (Studi Di Pengadilan Negeri Mojokerto)." Jurnal Hukum.

Noviana, Gloria Adita. 2018. "Tinjauan Yuridis Tindak Pidana Pencurian Pemberatan Yang Dilakukan Oleh Anak (Studi Kasus Putusan Nomor: 08/Pid.Sus Anak/2017/PN.Sel).” Universitas Mataram.

Nugroho, Wahyu. 2012. "Disparitas Hukuman Dalam Perkara Pidana Pencurian Dengan Pemberatan." $5(3)$.

Pratama, Alan Wahyu, Umi Rozah, and A. M. Endah Sri. 2016. “Tinjauan Yuridis Terhadap Tindak Pidana Pencurian Dengan Pemberatan Yang Dilakukan Oleh Anak Secara Bersama-Sama (Studi Putusan NO.03/PIDSUSANAK/2015/PN.PWD).” Diponegoro Law Journal 5(3).

Rifai, Ahmad. 2010. Penemuan Hukum Oleh Hakim Dalam Persfektif Hukum Progresif. Jakarta: Sinar Grafika.

Setiawan, Marwan. 2015. Karakteristik Kriminalitas Anak Dan Remaja. Bogor: Ghalia Indonesia.

Soemitro, Irma S. 1990. Aspek Hukum Perlindungan Anak. Jakarta: Bumi Aksara.

Soesilo. 1984. Pokok-Pokok Hukum Pidana Peraturan UmumDan Delik-Delik Khusus. Bogor:Politea.

Tambalean, Pingkan. 2013. "Penegakan Hukum Atas Tindak Pidana Pencurian Yang Dilakukan Oleh Anak Di Bawah Umur." LEX ET SOCIETATIS 1(2).

Wafi, Abdul. 2019. "Penerapan Sanksi Pidana Terhadap Anak Sebagai Pelaku Tindak Pidana Pencurian Dengan Pemberatan (Putusan Nomor: 262/PID.SUS.ANAK/2014/PN.BLG).” Universitas Jember.

Zhasadoma, Ravinska Audina. 2015. "Tinjauan Terhadap Pemidanaan Tindak Pidana Pencurian Dengan Pemberatan Yang Dilakukan Oleh Anak (Analisis Putusan Nomor: 15/Pid.Sus/2014/Pn.Skh.).” Recidive 4(1).

UUD NRI Tahun 1945

KUHP

KUHAP

UU No. 48 Tahun 2009 tentang Kekuasaan Kehakiman

UU No. 11 Tahun 2012 tentang Sistem Peradilan Pidana Anak 